Ann. Parasitol. Hum. Comp., 1990, $65: \mathrm{n}^{\circ} 2,74-79$.

Mémoire.
Key-words: Chamois. Rupicapra rupicapra parva. Natural Infections. Broncho-pulmonary helminths. Neostrongylus. Muellerius. Protostrongylus.

Mots-clés : Chamois. Rupicapra rupicapra parva. Infestation naturelle. Helminthes bronchopulmonaires. Neostrongylus. Muellerius. Prostrongylus.

\title{
BRONCHO-PULMONARY HELMINTHS OF CHAMOIS (RUPICAPRA RUPICAPRA PARVA) CAPTURED IN NORTH-WEST SPAIN: ASSESSMENT FROM FIRST STAGE LARVAE IN FAECES AND LUNGS
}

\author{
P. DIEZ-BAÑOS*, N. DIEZ-BAÑOS**, M. P. MORRONDO-PELAYO*, M. CORDERO DEL CAMPILLO**
}

\section{SUMMARY}

The bronchopulmonary helminths of 66 chamois ( 49 males and 17 females), captured in various parts of the Cantabrian mountain range (N. W. Spain) in the autumn of 1983 , and in the summer and the autumn of 1984 , were studied. The animals were adult and aged between 2 and 16 years.

The lungs, trachea and faeces from the last section of the intestine were taken from each animal individually. The trachea and pulmonary larval nodules were dissected. First stage larvae (L-I) were obtained from finely cut up pulmonary tissue and from faeces by migration.

The number of larvae I per gram varied between 0.08 and 2,662 $(\bar{x}=151.5 \pm 59.5$ s. e. $)$ in the faecal samples, and between 0.03 and $1,733(\bar{x}=65.2 \pm 32.4$ s. e. $)$ in the pulmonary ones. There was a low correlation between the two sets of data.

When taking into account age and sex, no statistically significant differences were observed in relation to the number of larvae/gram found either in faeces or in pulmonary tissue, while there were statistically significant differences when considering the periods of sampling and reserve of origin, in relation to the larvae found in faeces and lungs, respectively.

Infections by three nematodes (Neostrongylus, Muellerius and Protostrongylus) were more common than those produced by two or one, in the lungs as well as in the faeces. The most common genus was Neostrongylus, followed by Muellerius, and no Cystocaulus or Dictyocaulus larvae were found.

RÉSUMÉ : Les helminthes bronchopulmonaires des chamois (Rupicapra rupicapra parva) abattus au nord-ouest de l'Espagne : estimations selon les numérations des larves du premier stade dans les fèces et les poumons.

On a étudié les parasites bronchopulmonaires de 66 chamois (49 mâles et 17 femelles) capturés pendant l'automne de 1983, l'été et l'automne de 1984 dans plusieurs lieux de la Cordillère Cantabrique (nord-ouest d'Espagne). Les animaux étaient adultes et âgés de 2 à 16 ans.

On a recueilli séparément poumons, trachée et fèces de la dernière partie de l'intestin de chacun des chamois. On a fait la dissection de la trachée et des nodules larvaires pulmonaires. On a obtenu, par migration, des larves du premier stade (L-I) du tissu pulmonaire divisé en morceaux et des fèces.

Dans les prélèvements fécaux le nombre de larves I par gramme oscillent entre 0,08 et $2662(\bar{x}=151,5 \pm 59,5$ s. e. $)$ et dans les poumons entre 0,03 et $1733(\bar{x}=65,2 \pm 32,4$ s. e. $)$. Il y a une faible correlation entre les deux séries de résultats.

On a tenu compte de l'âge et du sexe, sans observer des différences importantes par rapport au nombre de larves/gramme trouvées, tant dans les fèces que dans le tissu pulmonaire. Par contre, des différences existent selon les périodes de prélèvement et selon les reserves.

Les infestations simultanées par trois nématodes (Neostrongylus, Muellerius et Protostrongylus) sont plus fréquentes que celles produites par deux espèces de nématodes et une seule, aussi bien dans les poumons que dans les fèces. Le genre le plus abondant est Neostrongylus, suivi de Muellerius. Ni Cystocaulus ni Dictyocaulus n'ont pas été trouvés.
* Departamento Patología Animal (Parasitología y enfermedades parasitarias) Fac. Veterinaria Lugo, Univ. Santiago. (Spain).

** Departamento. Patología Animal (Sanidad Animal), Fac. Veterinaria, Univ. León. (Spain).

Accepté le : 23 avril 1990.

\section{INTRODUCTION}

As chamois study material is rarely available, the number of studies carried out on bronchopulmonary parasites from 1932 to the present day is less than 40 and particularly limited in spain.

The purpose of this work is to establish possible differences due to age, sex, periods of sampling and origin of 
the animals, and to study the relationship existing between the number of larvae per gram found in faeces and lungs.

\section{MATERIAL AND METHODS}

The data referring to the age, sex, periods of sampling and origin of 66 chamois ( 49 males and 17 females) can be seen in Table I. As Fig. 1 shows, two Reserves are in the province of León (Mampodre and Riaño) and one is in Asturias (Reres). The areas of these three game reserves are: 73214 Ha (Riaño), 29238 (Mampodre) and 14227 (Reres). Riaño has the highest average altitude $(1420 \mathrm{~m})$ and Reres the lowest one $(700 \mathrm{~m})$; nevertheless, there are altitudes higher than $1800 \mathrm{~m}$ in all the reserves, where chamois are most frequently found and whose pastures are of alpine type (maximal altitudes up to $2536 \mathrm{~m}$ in Riaño, 2190 in Mampodre and 2022 in Reres). The average annual temperatures are simular in Riaño and Mampodre $\left(8.4\right.$ and $\left.9.1^{\circ} \mathrm{C}\right)$ and their average pluviosities are 1266 and $144 \mathrm{~mm}$ respectively, with dry and warm periods followed by wet and cold ones. The climate in the reserve of Reres is milder, its average annual temperature being $13.5^{\circ} \mathrm{C}$ and its pluviosity $1,300 \mathrm{~mm}$, but its monthly distribution is more uniform than in the other reserves.

As regards the density of chamois per $\mathrm{Ha}$, Reres presents the highest number of animals $(0.15)$ and Riaño and Mampodre the lowest ones ( 0.02 and less than 0.01 , respectively).

The fresh lungs were opened longitudinally and, after placing then under running water, the lavage was poured into a container to collect the adult worms and/or larvae present. A direct examination of the lesions on the dorsal and basal edges of the lungs was carried out. The presence and distribution of verminous nodules were recorded. The larval nodules were dissected and the scrapings were examined under a microscope to detect eggs and/or larvae. The fresh lungs were weighed, and then cut up and placed in 8-10 small bags, using the Baermann method to assess the number of first stage larvae (L-I) per gram. The same method was used to obtain the L-I in the fresh faeces collected from the intestine.

The L-I count was carried out using Favati or McMaster chambers, depending on the number. When there were fewer than 100 , all of them were identified (in accordance with Gebauer (1932), Boev (1975), Sattlerová (1982) and Švarc (1984); if there were more, approximately $30 \%$ were studied.

Variance analysis was used to establish the possible differences between the absolute number of larvae per gram in the faecal and pulmonary samples with regard to age, sex, periods of sampling and reserve from which the animals came.

Regression analysis was used to relate the numbers of larvae

TABLE I. - Number of animals captured, taking into account: sex, age, periods of sampling and reserve from which the chamois came.

\begin{tabular}{cccc}
\hline & & \multicolumn{2}{c}{ Sex } \\
\cline { 3 - 4 } & & Males & Females \\
\hline Age & 2 to 6 & 18 & 0 \\
(years old) & 7 to 11 & 25 & 5 \\
& 12 to 16 & 6 & 12 \\
\hline Periods & Autumn 83 & 11 & 4 \\
of & Summer 84 & 24 & 1 \\
sampling & Autumn 84 & 14 & 12 \\
\hline Reserve & Mampodre & 22 & 0 \\
& Reres & 13 & 16 \\
& Riaño & 14 & 1 \\
\hline
\end{tabular}

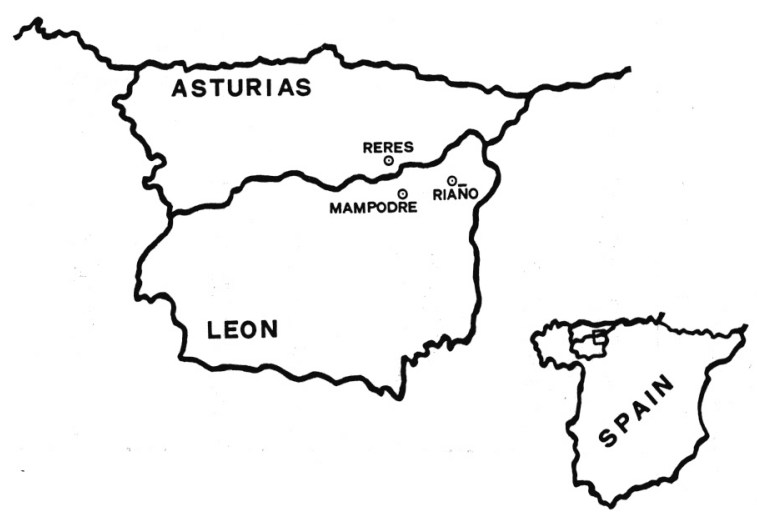

Fig. 1. - Geographical situation

of the Reserves where the chamois were captured.

per gram found in faeces and lungs and to relate the larvae per gram of the different genera of nematodes discovered in both samples.

The probability of infection was calculated for each genus ( $\mathrm{P}=\mathrm{n}^{\circ}$ of infected $/ \mathrm{n}^{\circ}$ of studied). The probability of infection by two or more genera was also estimated in order to study possible generic interaction.

The statistical analyses were carried out using the Statgraphics programme (Statistical Graphics Corporation, EXE (1986). Version: 2.1 ).

\section{RESULTS}

A high percentage of chamois presented Protostrongylidae larvae in faeces (90.8) and lungs (93.5). There were no important differences between the percentages for male and female animals with parasites. $91.7 \%$ of the former had larvae in faeces and $95.6 \%$ in the lungs; parasitation percentages for the latter were 88.2 and 87.5 respectively.

Pulmonary lesions were generally more common in the dorsal area than in the ventral one. The nodules were located on the upper dorsal and basal edges of the diaphragmatic lobe. There were visible lesions on aproximately $15 \%$ of the pulmonary surface, as evaluated according to Cordero et al. (1982), adapted to the chamois lung. Adult worms of Muellerius, Neostrongylus and Protostrongylus were present, but no adults Dictyocaulus were found in the trachea and large bronchi, which tallies with the absence of L-I in the lungs and faeces.

There were marked differences in the figures for L-I, some of which indicated important infections while others were less clear. The number of L-I per gram varied between 0.08 and $2,662(\bar{x}=151.5 \pm 59.5 \mathrm{~s}$. e.) in the faecal samples and between 0.003 and 1,733 $(\bar{x}=65.2$ \pm 32.4 s. e.) in the pulmonary ones. Linear regression analysis was applied to the number of larvae/gram found in faeces and lungs, and it was noted that there was low correlation ( $r=0.44 \pm 0.119$ s. e.).

When age, sex, periods of sampling and reserve from 


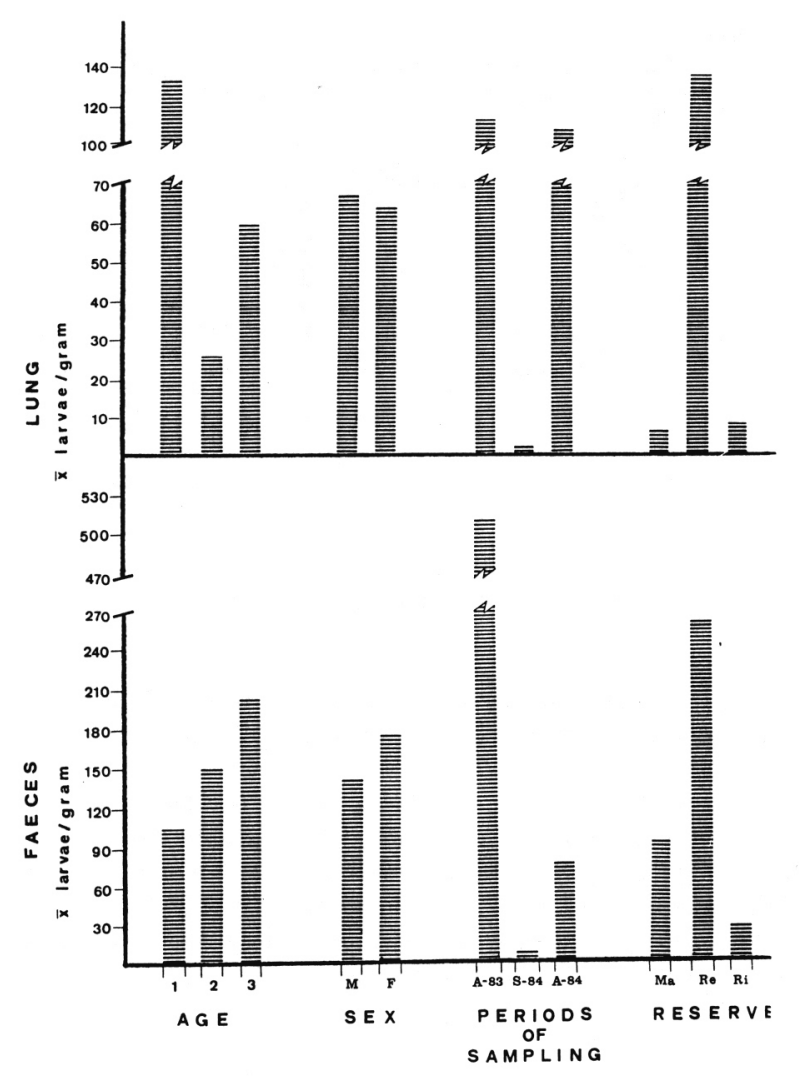

FIG. 2. - Comparative results of the average number of larvae/gram obtained from faeces and lungs, taking into account: Age (1. -2 to 6 years old, 2. -7 to 11 years old, 3. 12 to 16 years old), sex (M. - male, F. - female), periods of sampling (A-83. - Autumn 1983, S-84. - Summer 1984, A-84. - Autumne 1984), and Reserve from which the chamois came (Ma. - Mampodre, Re. - Reres, Ri. - Riaño).

which the chamois came were taken into account (fig. 2), it was observed that the number of larvae/gram in the faecal samples as well as in the pulmonary ones was higher in the animals from the Reres National Reserve. No important variation was registered as far as sex was concerned. However, the average number of larvae present in faeces increased with age, whilst the number found in the lungs was higher for the younger animals. When considering the periods of sampling, it was observed that, in both types of samples, animals were more parasitised in the autumn than in the summer. When variance analysis was applied, no statistically significant differences were noted for the number of larvae found in faeces, with regard to sex $(\mathrm{F}=0.787, p=0.39)$, age $(\mathrm{F}=0.133, p=0.87)$ and reserve $(\mathrm{F}=1.22, p=0.30)$, whilst the differences related to periods of sampling $(\mathrm{F}=5.780 p=0.005)$ were statistically significant.

When applying the same analysis to the pulmonary samples, no statistically significant differences were noticed with regard to sex $(\mathrm{F}=1.533, p=0.221)$, periods of sampling $(\mathrm{F}=2.066, p=0.137)$, and age $(\mathrm{F}=0.859, p=0.429)$,

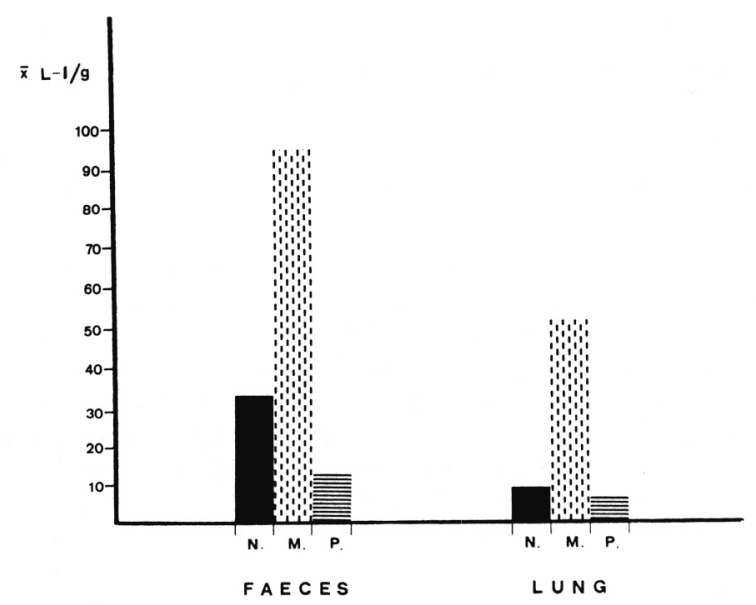

Fig. 3. - Comparative results of the average number of larvae/gram of Muellerius (M.), Neostrongylus (N.) and Protostrongylus (P.) obtained from faeces and lungs.

whilst the differences related to reserve $(F=3.305$, $p=0.05$ ) were statistically significant. As regards age, sex, periods of sampling and origin, the groups were also observed to be homogeneous by means of multiple range analysis; this does not apply to the faecal samples when taking into account the periods of sampling of the animals, nor to the pulmonar samples when considering the reserve.

Neostrongylus, Muellerius and Protostrongylus larvae were identified. Figure 3 shows the average number of larvae I per gram of these nematodes in faeces and lungs. The correlations, in absolute numbers, between the larvae I of these nematodes in faeces and lungs were: $r=0.68$ \pm 67.1 s. e. for Neostrongylus, $r=0.40+27.1$ s. e. for Muellerius and $r=0.45 \pm 33 . \mathrm{Z}$ s. e. for Protostrongylus. Therefore, high significant differences were observed for Neostrongylus and low ones for Muellerius and Protostrongylus.

As can be seen in table II, the infections by two and three nematodes were more common than those by one, in faeces as well as in lungs. Neostrongylus predominated in the cases of one single nematode. The absence of the Muellerius and Protostrongylus combination also needs to be pointed out.

By means of probability calculus (table II), it was established that there are no positive interactions between the different genera of nematodes.

\section{DISCUSSION}

The works carried out on pulmonary nematodes in chamois can be seen in table III. The country and, where applicable, the origin and other data concerning the number of animals examined and percentage of parasitised ones, 
TABLE II. - Percentages for the different types of infection produced by one single nematode, by two, or by three (N. = Neostrongylus, M. = Muellerius, $\mathbf{P} .=$ Protostrongylus $)$ and probability of infection by each genera and their possible associations.

\begin{tabular}{|c|c|c|c|c|c|c|c|}
\hline \multirow{2}{*}{$\begin{array}{l}\text { Material } \\
\text { exam. }\end{array}$} & & \multicolumn{3}{|c|}{$\%$ Pure } & \multicolumn{2}{|c|}{$\%$ Double } & $\%$ Triple \\
\hline & & $N$ & $M$ & $P$. & $N .+M$ & $N .+P$. & $N .+M .+P$. \\
\hline \multirow{2}{*}{ Faeces } & percentage & 21.4 & 1.8 & 0.0 & 39.3 & 7.1 & 30.4 \\
\hline & probability & 0.8 & 0.6 & 0.3 & 0.3 & 0.1 & 0.3 \\
\hline \multirow{2}{*}{ Lung } & percentage & 25.0 & 3.8 & 1.9 & 32.7 & 5.8 & 30.8 \\
\hline & probability & 0.8 & 0.6 & 0.3 & 0.3 & 0.1 & 0.3 \\
\hline
\end{tabular}

as well as the nematode genera reported, are also indicated. It has to be pointed out that most studies have been carried out on the respiratory apparatus (trachea, bronchi and lungs) and very few on faecal material.

Dictyocaulus was not observed in this study, which we think might be due to age (animals older than two years). However, Bidoveč et al. (1985), Dollinger (1974), Genchi et al. (1984), Hörning and Wandeler (1968), Rojo and Cordero (personal communication), and Sikó and Negus (1988) have reported low parasitation percentages for Dictyocaulidae.

As was stated above, Neostrongylus, Muellerius and Protostrongylus genera were identified. The high intensity of the first two parasites tallies with the idea that they are well adapted to chamois, and that their cycles are followed in a normal manner in the habitat in which these small ruminants live. Moreover, the first two genera are the most frequently mentioned by the majority of authors (table III). The absence of Cystocaulus, which often parasitises sheep, should be emphasized. Nevertheless, this nematode has been found only in chamois by Bidoveč et al. (1985). Díez et al. (1984), and Genchi et al. (1984).

The prevalence for Protostrongylidae larvae in the lungs was high. It was similar to the one recorded by Stroh (1936), Genchi et al. (1984), Švarc (1984a, b), and Bidoveč et al. (1985), and higher than the one cited by Balbo et al. (1975), Dollinger (1974), Nocture (1986), Schröder (1971, cit. by Salzmann and Hörning, 1974), and Rojo and Cordero (personal communication). The nematode most frequently recorded by us was Neostrongylus, which coincides with what was observed by Hugonnet and Euzéby (1980), and Hugonnet et al. (1981) in lungs taken from chamois from the Bauges National Reserve and the Vanoise National Park (France). Those authors as well as Brglez et al. (1974, cit. by Hugonnet and Euzéby, 1980), Hugonnet et al. (1981), Hörning (1975), Kutzer and Hinaidy (1969), Stroh (1936), Nocture (1986), and Díez et al. (1987) indicated Neostrongylus, Muellerius and Protostrongylus as the most common association, which concurs with our results. Only Genchi et al. (1984) and Bidoveč et al. (1985) found cha- mois with lungs parasitised by a high percentage of Cytocaulus ocreatus, associated with Muellerius capillaris, Neostrongylus linearis, and three species of Protostrongylus. In a previous study (Díez et al., 1984) $N$. linearis, Muellerius spp., and Protostrongylus spp., with a small percentage of Cystocaulus spp., larvae were identified in one chamois lung (table III).

Sattlerová $(1982,1987)$ verified that $100 \%$ of the chamois in the Tatra National Park (Czechoslovakia) eliminated L-I in faeces, which is slightly higher than the parasitation percentage obtained by us.

The absence of correlation between the number of larvae I per gram found in faeces and in lung might indicate that, usually, one single coprologic analysis is not enough to establish the degree of parasitation of chamois. This hypothesis had been previously formulated for domestic ruminants by Cordero et al. (1982), and for chamois by Díez et al. (1987). However, Forrester (1973) observed in « bighorn » sheep (Ovis canadiensis) a certain correlation between Protostrongylus larvae I found in faeces and in lungs, when comparing average values of several herds; but no significant correlation was obtained by comparing samples from one single herd.

In the youngest chamois the number of L-I per gram of pulmonary tissue was higher than in the oldest ones. This tallies, to some extent, with the results of Hugonnet and Euzéby (1980), who noticed a higher prevalence in one year old chamois than in two to five month old ones. However, Bidoveč et al. (1985) report that the lungs of the oldest animals are the most parasitised.

The animals, specially the oldest ones, eliminated a large number of L-I in faeces. This is of great epizootiologic interest, since the oldest chamois would play a very active part in the maintenance of the parasitation of the herd.

The chamois eliminated important number of L-I during all the periods of sampling. This coincides with what was observed by Salzmann and Hörning (1974). However, the number of L-I per gram of faeces was larger in autumn than in summer. This tallies with the results if Hugonnet and Euzéby (1980), Hugonnet et al. (1981), and Nocture 


\section{P. DIEZ-BAÑOS, N. DIEZ-BAÑOS, M. P. MORRONDO-PELAYO, M. CORDERO DEL CAMPILLO}

TABLE III. - Data quoted by other authors in reference to: Number of chamois examined (No. of cha. exam.); material examined (Mat., F. = faeces, L. = lung); Dictyocaulidae genus (Dict. = Dictyocaulus); and Protostrongylidae genera $($ Cyst. $=$ Cystocaulus, Muell. $=$ Muellerius, Neost. $=$ Neostrongylus, Prot. $=$ Protostrongylus $), \stackrel{\bullet}{=}$ the authors do not specify: number of chamois studied, material examined, and/or percentages of parasitation.

\begin{tabular}{|c|c|c|c|c|c|c|c|c|c|c|c|}
\hline \multirow[b]{2}{*}{ Country } & \multirow[b]{2}{*}{ Reserve } & \multirow[b]{2}{*}{ Authors } & \multirow{2}{*}{$\begin{array}{l}N^{\circ} \\
\text { of } \\
\text { cham } \\
\text { exam }\end{array}$} & \multirow[b]{2}{*}{ Mat. } & \multicolumn{2}{|c|}{ Dictyocaulidae } & \multicolumn{5}{|c|}{ Protostrongylidae } \\
\hline & & & & & $\%$ Par. & Dict. & $\%$ Par. & Cyst. & Muell. & Neost. & Prot. \\
\hline \multirow[t]{2}{*}{ Austria } & $\ldots .$. & Gebauer & - & $\mathrm{L}$ & - & $\mathrm{X}$ & - & & $\dot{x}$ & $\mathrm{X}$ & $\mathrm{X}$ \\
\hline & $\ldots$. & Kutzer \& Hinaidy & - & $\mathrm{L}$ & 0 & & $\bullet$ & & $\mathrm{X}$ & $\mathrm{X}$ & $\mathrm{X}$ \\
\hline \multirow{6}{*}{$\begin{array}{l}\text { Czechoslo- } \\
\text { vakia }\end{array}$} & Tartra, Jseniky & Erhardova (cit. Svarc, 1984 a) & - & $\mathrm{L}$ & - & $\mathrm{X}$ & - & & $\mathrm{X}$ & $\mathrm{X}$ & \\
\hline & $\ldots .$. & Kotzla \& Kotly (cit. Hugonnet \& Euzéby, 1980) & - & $\mathrm{L}$ & 0 & & - & & $\mathrm{X}$ & $\mathrm{X}$ & $\mathrm{x}$ \\
\hline & Tatra & Sattlerova & - & $\mathrm{F}$ & 0 & & $\bullet$ & & $\mathrm{X}$ & $\mathrm{X}$ & \\
\hline & Tatra & Sattlerova & - & $\mathrm{F}$ & 0 & 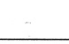 & 100 & & $\mathrm{X}$ & $\mathrm{X}$ & \\
\hline & $\ldots$. & Svarc & 21 & $\mathrm{~F} / \mathrm{L}$ & 0 & & 100 & & $\mathrm{X}$ & $\mathrm{x}$ & \\
\hline & $\ldots$. & Švarc \& Zmoray & $\bullet$ & $\mathrm{L}$ & 0 & & $\bullet$ & & $\mathrm{X}$ & & \\
\hline \multirow[t]{4}{*}{ France } & Bauges & Hugonnet \& Euzéby & $\bullet$ & $\mathrm{L}$ & - & $\mathrm{X}$ & - & & $\mathrm{x}$ & $\mathrm{X}$ & $\mathrm{x}$ \\
\hline & Vanoise & Hugonnet et al. & $\bullet$ & $\mathrm{L}$ & - & $\mathrm{X}$ & - & & $\mathrm{X}$ & $\mathrm{X}$ & $\mathrm{x}$ \\
\hline & Bauges & Nocture & 51 & $\mathrm{~F} / \mathrm{L}$ & 0 & & 35.2 & & $\mathrm{X}$ & $\mathrm{X}$ & $\mathrm{X}$ \\
\hline & Bauges & Ventejou (cit. Nocture, 1986) & $\bullet$ & $\mathrm{L}$ & - & $\mathrm{X}$ & - & & $\mathrm{X}$ & $\mathrm{X}$ & $\mathrm{X}$ \\
\hline \multirow[t]{4}{*}{ Germany } & Alps & Knaus \& Schröder (cit. Švarc, $1984 a$ ) & - & • & - & $\mathrm{X}$ & - & & $\mathrm{X}$ & & $\mathrm{X}$ \\
\hline & Alps & Schröder (cit. Salzmann \& Hörning, 1974) & 10 & - & 0 & & 50 & & $\mathrm{X}$ & $\mathrm{X}$ & ' \\
\hline & $\ldots .$. & Stroh & 100 & $\mathrm{~L}$ & 0 & & 98 & & $\mathrm{X}$ & $\mathrm{X}$ & $\mathrm{X}$ \\
\hline & $\ldots+\ldots$ & Wetzel \& Rieck (cit. Hugonnet \& Euzéby, 1980) & - & • & - & $\mathrm{X}$ & 0 & & & & \\
\hline \multirow[t]{6}{*}{ Italy } & Gran Paradiso & Balbo & - & $\mathrm{L}$ & - & $\mathrm{x}$ & - & & & & $\mathrm{x}$ \\
\hline & Gran Paradiso & Balbo et al. & 71 & $\mathrm{~L}$ & 0 & & 8.4 & & & & $\mathrm{x}$ \\
\hline & Gran Paradiso & Biocca et al. & - & $\mathrm{L}$ & 0 & & - & & & & $x$ \\
\hline & Abruzzo & Cancrini et al. & 21 & $\mathrm{~L}$ & 0 & & 47.6 & & & & $X$ \\
\hline & $\begin{array}{l}\text { Val Belviso } \\
\text { Stelvio }\end{array}$ & Genchi et al. & $\begin{array}{l}20 \\
18 \\
\end{array}$ & $\begin{array}{l}\mathrm{L} \\
\mathrm{L}\end{array}$ & 0.8 & $\mathrm{X}$ & $\begin{array}{l}95 \\
88.8 \\
\end{array}$ & $\begin{array}{l}X \\
X\end{array}$ & $\begin{array}{l}X \\
X \\
\end{array}$ & $\begin{array}{l}X \\
X \\
\end{array}$ & $\begin{array}{l}X \\
X \\
\end{array}$ \\
\hline & Gran Paradiso & Mandelli & - & $\mathrm{L}$ & 0 & & - & & $\mathrm{X}$ & & \\
\hline New Zealand & $\ldots$. & Clark \& Clarke & 28 & $\mathrm{~L}$ & - & $\mathrm{X}$ & - & & $x$ & & \\
\hline Romania & $\ldots$. & Siko \& Negus & • & $\mathrm{F}$ & 5 & $\mathrm{X}$ & 0 & & & & 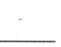 \\
\hline Scotland & $\ldots$. & Dunn & - & $\bullet$ & • & $\mathrm{X}$ & - & 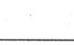 & $\mathrm{X}$ & $\mathrm{X}$ & $\mathrm{X}$ \\
\hline \multirow[t]{3}{*}{ Spain } & Mampodre, Riaño, Reres & Díez et al. & 14 & $\mathrm{~F} / \mathrm{L}$ & 0 & & 100 & $\mathrm{x}$ & $\mathrm{X}$ & & $\mathrm{x}$ \\
\hline & Mampodre, Riaño, Reres & Díez et al. & 15 & $\mathrm{~F} / \mathrm{L}$ & 0 & & 100 & & $\mathrm{X}$ & $\mathrm{X}$ & $\mathrm{X}$ \\
\hline & Reres & Rojo \& Cordero (pers. con.) & 42 & $\mathrm{~L}$ & - & $\mathrm{X}$ & $\bullet$ & & & & $\mathrm{X}$ \\
\hline \multirow[t]{4}{*}{ Switzerland } & Alps & Dollinger & 213 & $\mathrm{~L}$ & 0.5 & $\mathrm{X}$ & 53.5 & . & & $\mathrm{X}$ & $\mathrm{X}$ \\
\hline & $\ldots \ldots$ & Hörning & - & - & $\bullet$ & $\mathrm{X}$ & - & 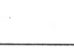 & $\mathrm{X}$ & $\mathrm{X}$ & $\mathrm{X}$ \\
\hline & $\ldots \ldots$ & Hörning \& Wandeler & 101 & $\mathrm{~L}$ & 3.9 & $\mathrm{X}$ & 59 & & & & $\mathrm{X}$ \\
\hline & Jura & Salzmann \& Hörning & 75 & $\mathrm{~L}$ & - & $\mathrm{X}$ & - & & $\mathrm{X}$ & & $\mathrm{X}$ \\
\hline \multirow[t]{3}{*}{ USSR } & Georgia & Moseliani \& Rodonaya & - & $\mathrm{L}$ & 0 & & • & & $\mathrm{X}$ & & \\
\hline & Central Caucașus & Pupkov & - & $\mathrm{L}$ & 0 & & - & 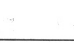 & & $\mathrm{x}$ & $\mathrm{x}$ \\
\hline & Caucasus & Rukhlvadev & - & $\mathrm{L}$ & 0 & 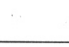 & - & $i$ & & $\mathrm{x}$ & \\
\hline \multirow[t]{3}{*}{ Yugoslavia } & $\underline{\text { Slovenia }}$ & Bidoveč et al. & 1,232 & $\mathrm{~L}$ & 0.4 & $\mathrm{X}$ & 83.2 & $\mathrm{X}$ & $\mathrm{X}$ & $\mathrm{X}$ & $x$ \\
\hline & Slovenia & Brglez et al. (cit. Hugonnet \& Euzéby, 1980) & - & $\mathrm{L}$ & 0 & & - & & $\mathrm{X}$ & $\mathrm{x}$ & $\mathrm{X}$ \\
\hline & Treskavica & Delic \& Cankovic & 2 & $\mathrm{~L}$ & 0 & & $\therefore$ & & & & $\mathrm{X}$ \\
\hline
\end{tabular}


(1986), who reported that parasitic diseases caused by pulmonary nematodes are seasonal in the chamois.

In this work a different prevalence and intensity of parasitation have been observed, depending on the reserve of origin. This fact tallies with what Salzmann and Hörning (1974), Hugonnet et al. (1981), and Bidoveč et al. (1985) noticed for chamois from different National Parks in Switzerland, France and Yugoslavia, respectively. This phenomenon may be due to the presence, in each area, of molluscs which act as intermediate hosts more or less adequate for these nematodes, as well as to edafoclimatic differences between the areas, which affect the survival of L-I of these Protostrongylidae.

\section{REFERENCES}

Balbo T. : Indagini sulla situazione parassitologica nei mammiferi del Parco Nazionale del Gran Paradiso. Parassitologia, 1973, 15, 301-312.

Balbo T., Costantini R., Peracino V. : Indagini sulla diffusione dei nematodi polmonari nello stambecco (Capra ibex) e nel camoscio (Rupicapra rupicapra) del Parco Nazionale del Gran Paradiso e della Riserva di Valdieri. Parassitologia., 1975, 17, 65-68.

Biocca E., Balbo T., Costantini R. : Protostrongylus (Protostrongylus) rufescens boevi subspecies nova, parassita dell'apparato respiratorio del camoscio. Parassitologia., 1976, 18, 33-40.

Boev S. N. : Osnovy nematologii. XXV. Protostrongilidy (K. M. Ryzhikov edit.) Moscú. Izd. Nauka, 1975. 1-264.

Bidoveč A., Valentincič S., Kuses M. : Parasitic pneumonia in chamois (Rupicapra rupicapra L.) in Slovenia. In: The biology and management of mountain ungulates. S. Lovary (edit.), 1985, 240-242.

Cancrini G., Iori A., Rossi L., Fico R. : Occurrence of Pulmonary and Gastrointestinal Nematodes in the Abruzzo chamois. In: The biology and management of mountain ungulates (S. Lovari, Ed.), Croom Helm, London, 1985, 256-257.

Clark W. C., Clarke C. M. H. : Parasites of chamois in New Zealand. N. Z. vet. J., 1981, 29, 144.

Cordero M. Díez P., Reguera A., Rojo F. A. : Critical experiments with Albendazole in the treatment of Protostrongylid infection of sheep. Rev. Iber. Paristol., 1982, Vol. extra, 543-553.

Delić S., Canković M. : Prilog poznavanju parasitofaune divokoze (Rupicapra rupicapra L.) sa producja planine Treskavice. Veterinaria Sarajevo., 1961, 10, 483-485.

Díez P., Díez N., Antón A. : Aportaciones al conocimiento de los nematodos pulmonares del rebeco (Rupicapra rupicapra) de la Cordillera Cantábrica. IV Reunión Anual de la A. P. E., 1984, 61 .

Díez P., Díez N., Antón A., Morrondo M. P. : Principales problemas parasitarios del rebeco en la Cordillera Cantábrica. Actas Jornadas de Estudio de la Montan̆a. Edit. U. R. Z., 1987, 337-350.

Dollinger P. : Contribution to the knowledge of the endoparasite faune of the chamois (Rupicapra rupicapra) in Switzerland. Z. Jagdwiss., 1974, 20, 115-118.

Dunn A. M. : The wild ruminant as reservoir host of helminth infection. Symp. Zool. Soc. London., 1969, 24, 221-248.

Forrester D. J. : (Complejo estrongilosis pulmonar-neumona de la oveja bighorn). In: Enfermedades parasitarias de los Mamíferos Salvajes (Acribia, Ed.), 1973, 185-203.
Gebauer O. : Zur Kenntnis der Parasitenfauna der Gemse. $Z$. Parasitenkd., 1932, 4, 147-219.

Genchi C., Manfredi M. T., Sioli C. : Les infestations naturelles des chèvres par les strongles pulmonaires en milieu alpin. Les maladies de la chèvre, Niort (France), 9-11 octobre 1984, INRA, $28,347-352$.

Hörning B. : Die Rolle des Parasitenbefalls in den Wildbeständen. Schweiz. Z. Forstwesen., 1975, 5, 361-372.

Hörning B., Wandeler A. : Der Lungenwurmbefall von Reh und Gemse in einigen Gebieten der Schweiz. Rev. Suisse Zool., 1968, 75, 597-608

Hugonnet L., Euzéby J. : Le parasitisme chez les jeunes chamois de la réserve naturelle des Bauges. Bull. Acad. Vét. de France, 1980, 53, 77-85.

Hugonnet L., Montagut G., Euzéby J. : Incidences réciproques des infestations helminthiques des ruminants sauvages et des ovins domestiques en alpage en Vanoise. Bull. Soc. Sci. Vét. Méd. Comp., 1981, 83, 193-199.

Kutzer E., Hinaidy H. K. : Die Parasiten der wildlebenden Wiederkäuer Österreichs. Z. Parasitenk., 1969, 32, 354-368.

Mandelli G. : Lesioni bronco-pulmonari de elminti nei camosci (Rupicapra rupicapra L.) e negli stambecchi (Capra ibex L.) del Parco Nationale del Gran Paradiso. Reperti anatomoistologici e considerazioni patogenetiche. Clin. Vet. Milan, 1959, 82, 225-248.

Moseliani D. V., Rodonaya T. E. : (Muellerius infection of domestic and wild animals in the Georgian S. S. R.). Soobshch. Akad. Nauk gruz. SSR., 1962, 28, 79-80.

Nocture M. : Étude de l'infestation des paturages d'altitude par les « strongles » des chamois. Thèse Doct. Vet., Lyon, 1986, $109 \mathrm{p}$.

Pupkov P. M. : (Helminth fauna of Rupicapra rupicapra caucasica in Central Caucasus). Trudy Gorskogo Gel'skokhozyaistvennogo Inst. Yubileinyi., 1971, 32, 331-333.

Rukhlyadev D. P. : (The lung nematode Neostrongylus linearis (Marotel, 1913) in wild ruminants in the Caucasus). Trudy gel'mint. Lab. Akad. Nauk. SSR., 1950, 4, 133-135.

Salzmann H. C., Hörning B. : Der parasitologische Zustand von Gemspopulationen des Schweizerischen Juras im Vergleich zu Alpengemsen. Z. Jadwiss., 1974, 20, 105-115.

Sattlerová A. : The resistance of first stage larvae of Muellerius spp. and Neostrongylus linearis (from the feces of chamois, Rupicapra $r$. tatrica) to different physical factors under laboratory and natural conditions. Helminthologia, 1982, 19, 151-160.

Sattlerová A. : (Ecological conditions for lungworm infections of chamois in the Tatra National Park). Biologia (Bratislava), 1987, 42, 113-119.

Sikó S. B., Negus S. : Aspects of the interrelations between parasitofauna of chamois (Rupicapra rupicapra carpatica, Couturier, 1938) and sheep (Ovis aries L.) from the same trophic areas. Erkrankungen der Zootiere. Verhandlungsbericht des 30 Internat. Symp. über die Erkrankungen der Zoo-und Wildtiere Vonn 11, 1988, 139-148.

Stroh G. : Lungenwurmfunde bei 100 Gemsen und ihre krankmachende Bedeutung. Berl. Tztl. Wschr., 1936, 43, 696-699.

Švarc R. : Pulmonary nematodes of the chamois Rupicapra rupicapra tatrica, Blahout, 1971. I. Pathomorphological picture of lungs during the development of worms into the adult stage. Helminthologia, 1984, 21, 141-149.

Švarc R. : Pulmonary nematodes of the chamois Rupicapra rupicapra tatrica, Blahout, 1971. 2. Pathomorphological picture of lungs induced by the sexually productive worms. Helminthologia, 1984, 21, 303-313.

Švarc R., Zmoray I. : Die Entwicklung von Müllerius tenuispiculatus Gebauer, 1932 Bei Zwischenwirten unter experimentellen Bedingungen. Biologia (Bratislava), 1973, 28, 379-388. 